\title{
1. Precedence in perspective
}

\author{
James J. Fox
}

\section{The use of precedence in Austronesian ethnography}

The concept of precedence defines a relative relationship. It is significant not in its focus on this single relationship but rather in the possibility it offers for a concatenation of relationships, thus producing an 'order of precedence' in which relations are recursively arrayed asymmetrically one to another. As such, precedence involves the conjunction of two analytic categories: recursive complementarity and categorical asymmetry (Fox 1994). A complementary category consisting of two elements - one of which is considered as 'anterior' or 'superior' to the other, such 'elder' $>$ 'younger', 'first-born' $>$ 'last-born' or 'trunk' $>$ 'tip' - is applied in recursive, or repeated fashion, to produce an ordered series. This series is an 'order of precedence'.

Importantly, an 'order of precedence' can operate at various levels, differentiating relations within families, within larger social groups or throughout an entire society. The bases for the construction of precedence at different social levels may vary and, significantly, may be contested, reversed and reordered. This volume is taken up with the discussion of all of these possibilities. Each of the papers that comprise this volume explores the concept of precedence in the analysis of particular Austronesian-speaking societies.

The notion of precedence is hardly new to anthropology, particularly in the study of the Austronesians of the Pacific Islands. In Kings and Councillors, for example, A. M. Hocart refers to an 'order of precedence' in his discussion of the foundations of social differentiation (1970: 37). ${ }^{\text {l }}$ Similarly, Irving Goldman, in his examination of contending principles of status in his study, Ancient Polynesian Society, argues that aristocratic rank rested upon 'a base of orderly precedence' but 'alternations in orders of precedence' were subject to 'changing estimations of chiefly power' and 'changing balances of power among contending parties' (1970:16). Marshall Sahlins in his Social Stratification in Polynesia, adopts a more specific focus in his use of the notion of precedence. He distinguishes two types of social organization in the Pacific: the one a 'ramified' and the other a 'descent-line' system. Although precedence, as discussed in the volume, might equally be applied to both types of organization, Sahlins associates precedence with status differentiation in 'descent-line' systems. Thus he writes that titles in such systems 'are arranged in a traditional order of precedence symbolized by seating position in administrative councils (fonos) and in the order of kava serving at the meetings of such bodies and other ceremonial occasions' (1958: 194). The societies he is referring to in this context are Futuna, Uvea and Samoa 
and his discussion reflects the use of precedence in the ethnographies he relies upon. For example, Sahlins quotes Edwin Burrows' comment on high title figures on Uvea: 'The order of precedence among Ministers governs seniority among lineages, rather than being governed by it' (1958: 191). To cite yet another pertinent example from the Pacific, Francis Grimble in his study of the Gilbert Islands, Tungaru Traditions edited by H.E. Maude, devotes an entire chapter, 'Precedence and Privileges of the Clans in the Maneaba' (1989 219-230), to an examination of the subtle distinctions, particularly ceremonial, that differentiate other clans in relation to the preeminent clan, Karonga $n$ Uea. ${ }^{2}$

Similarly, Derek Freeman, in his London School of Economics thesis, The Social Structure of a Samoan Village Community — originally submitted in 1948 but only published posthumously in 2006 - makes a thoroughgoing use of the precedence in its social analysis of Samoan status. Although unavailable to Sahlins in his study and equally unknown, until its publication, to those involved in the Comparative Austronesian Project, Freeman provides a detailed examination of genealogies and lineage relations within a single village, that of Sa'anapu on the southern coast of the Samoan island of Upolu. In an attempt to provide a comprehensive understanding of titles and status in the village, he focuses considerable attention on relations within Sa'anapu's formal assembly (fono): its strict seating pattern, the differentiation of rights among different title holders (matai) and the expression of honorifics ( $f a^{\prime}$ alupega) required at all such gatherings. ${ }^{3}$ It is to these relations he applies the concept of precedence: 'All of the fa'alupega of a village community are arranged in a strict order of precedence corresponding exactly to the seating order of its fono ... For example, when a lineage matai enters the village fono all conversation is broken off until he takes his appointed place. As soon as he is seated, all the other matai present chant his fa'alupega in unison. It then falls to the newcomer to reciprocate this courtesy by reciting, in strict order of precedence, the fa'alupega of all the lineages (other than his own) represented at the fono' (2006:91).

Although certainly wide-spread in the study of Pacific ethnography, the use of the notion of precedence has not been confined to this region of the Austronesian world. Among Canberra-based anthropologists, precedence has been the subject of continuing discussion, especially in relation to Austronesian conceptions of origin (see Fox 1988, 1994, 1995). E. Douglas Lewis, first in his thesis, Tana Wai Brama (1983) and then in the publication of People of the Source: The Social and Ceremonial Order of Tana Wai Brama on Flores (1988), was the first to apply the concept of precedence in a systematic fashion to a specific ethnographic community, the Ata Tana Ai of central east Flores. Lewis used precedence to trace relations from clan, Ipir, as the 'source' of the domain of Wai Brama to other clans as well as to trace the ordering of houses within the clans of their founding mothers. Both usages of precedence were marshalled to explicate the Tana Ai idea of oda as 'sequence'. 
Following on Lewis' initial study, a succession of doctoral theses produced in the Research School of Pacific and Asian Studies in Canberra resulted in a series of publications, all of which utilized the concept of precedence in the analysis of a specific society in eastern Indonesia. In an order based on the date of their submission as theses rather than eventual publication date, these studies include: 1) Andrew McWilliam, Paths of Origin, Gates of Life: A Study of Place and Precedence in Southwest Timor (2002), 2) Andrea Molnar, Grandchildren of the Ga'e Ancestors: Social Organization and Cosmology among the Hoga Sara of Flores (2000), 3) Tom Therik, Wehali, The Female Land: Traditions of a Timorese Ritual Centre (2004), 4) Thomas Reuter, Custodians of the Sacred Mountains: Culture and Society in the Highlands of Bali (2002a) and The House of our Ancestors: Precedence and Dualism in the Highlands of Bali (2002b), and 5) Philipus Tule, Longing for the House of God, Dwelling in the House of the Ancestors: Local Belief, Christianity and Islam among the Kéo of Central Flores (2004). A number of theses that make use of the concept of precedence still remain to be published. ${ }^{4}$ Their authors have, however, written valuable papers, for the most part in various volumes of the Comparative Austronesian Project, that provide a clear idea of the direction of their research: Penelope Graham (1996), Michael Vischer (1996), Barbara Grimes (1996, 1997), Christine Boulan-Smit (2006) Minako Sakai (1997) and Philip Winn (2006). Others have also written on the use of precedence: Reuter has used precedence in a comparative analysis of various societies in Sumatra (1993); Lewis has compared precedence in the neighbouring societies of Tana 'Ai and Sikka (1996); while Fox has examined patterns of precedence in a number of societies of the Timor area and Flores (1996) and also specifically in relation to settlement formation among the Atoni Pah Meto of West Timor (1999). More recently, anthropologists have made use of the concepts of origin and precedence in the analysis of Austronesian societies elsewhere: Michael Scott in relation to the Arosi in the Solomon Islands $(2007,2008)$ and Harri Siikala in relation to Samoa and other Polynesian societies (2008).

\section{Papers in this volume}

The papers in this volume contribute to this widening discussion of precedence, both extending its scope and deepening the examination of specific aspects of it. This is the first volume of its kind to focus entirely on precedence and to provide an ethnographic articulation of an array of its uses among societies, many of which are closely related to one another. The comparative value of these papers is thus particularly pertinent.

Each of the 10 papers that comprise this volume offers a distinctive approach to its examination of precedence. Yet the papers relate closely to one another and are able to provide a variety of comparative reflections. The briefest of summaries gives some idea of the variety of these papers as well as their comparative significance. 
The first paper by Reuter deals with one of the most complex social articulations of precedence in Indonesia, that of the Bali Aga or 'Mountain Balinese'. Reuter provides a masterful examination of the Austronesian categorical bases by which these Hindu Balinese construct inter-village and intra-council relations within a ritual domain (banua) centred on temples, some of which are among the most ancient on Bali. The spatial organization for the expression of precedence in the seating of the 'council of elders' in a Bali Aga village offers immediate comparisons with similar seating arrangements elsewhere in the Austronesian-speaking world, such as those in a Samoan fono.

Greg Acciaioli's paper shifts focus to South Sulawesi. Like many of the papers in the volume - those by Reuter, Lewis, Forth, Smedal and Kaartineen Acciaioli's concern is to distinguish between hierarchy and precedence. His starting point is Dumont's notion of hierarchy but he carries forward from this starting point to examine different articulations of precedence. He focuses in particular on systems of 'apical demotion' or 'sinking status,' all of which involve the loss of status in the process of separation from a prestigious point of origin. Such systems place their emphasis on differentiation from a source rather than integration with that source. Geertz has convincingly described such a system for lowland Bali (1980); Fox, in his paper, describes a similar system for Termanu on the island of Rote; and, a similar dynamic underlies Sahlin's classification (1958) of so-called 'ramage' systems, such as on Tonga and Samoa in the Pacific (see H. Siikala 2008). The societies of South Sulawesi combine similar processes of status dilution based on an idiom of the loss of 'white blood' that has produced a complex intermeshing of status resulting from intermarriage among status levels.

The paper by Fox is concerned with precedence as a form of discourse and in particular with some of the more common categories, such as elder/younger or first-born/last-born, used by Austronesian-speakers to establish precedence distinctions. It is also concerned with the possibilities of categorical reversal as, for example, when the younger or last-born replaces the elder or first-born in a line of succession or when precedence by origin is overturned by the installation of the 'outsider' or 'stranger-king' (see Fox 2008). The focus in this case is the domain of Termanu on the island of Rote for which there exists a rich oral history that is intended to explain, even as it bolsters, precedence among clans.

Andrew McWilliam's paper continues the discussion of precedence as discourse, focusing on the use of the botanic idiom of 'trunk' and 'tip' in West Timor. The metaphor of the tree, in its many guises, is probably the most wide-spread source of imagery for conceptualizing the dynamics of growth, development, continuity and differentiation in Austronesian-speaking societies. McWilliam describes marriage relations among the Atoni Pah Meto as the 'tree of alliance' that provides 
a host of rich metaphors in which wife-givers are 'trunk fathers', the bride is 'the flower of the trunk' and groom is the 'twig' of another 'tree of origin'.

Each of the next four papers in this volume examines precedence in different social settings on the island of Flores. The first two papers - E. Douglas Lewis's comparison of the domains of Tana Wai Brama and Sikka and David Butterworth's examination of the Krowé region - deal with distinct social formations within a single language area - an area that Lewis, in his paper, calls an 'ethnological laboratory in miniature'.

This region of Flores is in fact named Sikka after the village (Sikka Natar) on the south coast that provided the ruling house of the colonial period. As such, the Rajadom of Sikka was a polity of places (tana). Each of its incorporated domains - large and small — acknowledged the authority and pre-eminence of the Raja of Sikka. As Lewis convincingly shows by reference to the histories of Sikka, the involvement of the Portuguese and then the Dutch transformed this arrangement, which was based on a form of precedence, into a hierarchy of social classes. This hierarchy had the House of the Raja at its pinnacle, a separate noble class that, in Dutch times, was assigned positions of rule in different areas, a large commoner class that embraced most of the population and an indentured class whose origins had been obliterated.

By contrast, Tana Wai Brama is a ceremonially ordered aggregation of five major clans, one among the many tana that comprise the Sikka region. As Lewis has shown (1988), its ritual dynamics are based on precedence among houses as well as precedence among its constituent clans. Butterworth's analysis is critical here. As he clearly notes, the 'structure of precedence of clans only operates within domains, not between domains'. Butterworth groups all the various local Krowé idioms into three analytic groups: first//subsequent, genitor//progeny and source//product and shows how they are used differentially in social life but come together in Krowé cosmology.

As in the case of Tana Wai Brama, precedence among the Krowé involves a profound cosmological conception in which the deity is the initial source and genitor of life. The clan acknowledged to have settled first in an area provides the tana pu'an or 'source of the domain' who must maintain the special link to the deity. This points to the radical political reordering achieved by the rulers of Sikka. Their precedence was not based on having arrived 'first'. Rather their histories insist, as Lewis explains, that they came on the 'second ship'. Hence the basis of Sikkanese rulers' claims to pre-eminence are those of a 'stranger-king' or, possibly more appropriately, those who mediated between the outside and the inside.

Like Lewis in his discussion of Sikka, Gregory Forth in his paper on Keo and Olaf Smedal in his paper on the Ngadha are both concerned with questions of the relationship between precedence and hierarchy. Both papers are 
focused on a region of central Flores, whose languages show linkages to one another (Fox 1998).

In his exquisitely detailed historical analysis of the structuring of a dual Keo village, Forth relies on analytic categories similar to those used by Butterworth. In the Keo case, these specific categories are 1) trunk/tip, 2) elder/younger and 3) mother/child. Although the mother/child category set have a temporal dimension, Forth views this particular binary set as constituting a 'whole/part' relationship. As such, he defines them as hierarchical 'wherein a greater part subsumes a lesser'. Thus he is able to argue that 'hierarchy and precedence, rather than denoting distinct or theoretically contrary principles of order, can define different aspects of one and the same order'.

Smedal's paper is both wide-ranging and salient. His ethnographic analysis focuses on the houses in Ngadha as 'simultaneously dwellings, corporate estates, ancestral abodes, ritual centres and repositories of heirloom sacra'. These Ngadha houses, including the land and persons they subsume, are classified in spatial terms as belonging to either a 'trunk side' or a 'tip side' and each house 'relates to any other of its side in an order of precedence'. Smedal goes on to consider the notion of values in relation to Ngadha nobles and what he calls the 'reproduction of ranked persons'. He also makes the relevant observation that contesting precedence does not represent a challenge to the system per se but is rather a competition among individuals or groups over the interpretation of particularities within it.

Kaartinen's paper encapsulates critical themes discussed throughout the volume. He is concerned with the idea 'localized origin' and, how in Kei society, various discourses are articulated on the basis of particular narratives of origin known as tum. He focuses much of his discussion on the relations between those who claim immigrant origins and those who maintain local or autochthonous origins. He also points to the ways that the concepts of precedence, on the one hand, and hierarchy, on the other hand, in the sense defined by Barraud in her own research on Kei (1990) resemble each other. 'Both involve asymmetric and complementary symbolic oppositions which are applied to social and cosmic relationships.' Barraud's understanding of hierarchy, however, implies a classification that embraces the whole of society, whereas precedence does not 'presuppose the existence of society as a whole' that focuses on metaphoric expressions that suggest processes of coming into existence.

Underpinning Kaartinen's analysis is a feature, both demographic and cultural, of all of the societies considered in this volume - one that is perhaps a feature of most Austronesian societies - namely the past historical mobility of populations. The Austronesians were and continue to be predominately mobile and their construction of society reflects a culture of mobility. Thus conceptions of the past, at whatever level they are enunciated, recount the movement and 
involvement of different ancestors and ancestral groups, resulting in narratives of multiple origins and the amalgamation of these groups in shaping present societies.

The final paper in this volume by Michael Vischer examines the use of precedence by means of an event-based analysis of the opening phase of a ceremonial cycle of sacrifices in one domain, Ko'a, on the tiny island of Palue off the north coast of Flores. The paper provides the setting for these ceremonial events and follows in meticulous detail the actions of its various participants in the negotiations and contestations over the performance of the ritual. The whole of this careful analysis is accompanied by a film, attached for viewing as part of this volume. Based on many years of research on Palué, Vischer's approach is altogether remarkable in its scope and, in many ways, unique in its perspicacious background understanding of the key actors involved in the ritual. The paper provides another distinctive presentation of the way in which the concept of precedence can be marshalled for social analysis.

Unlike some of the previous volumes in the Comparative Austronesian series that generally included a selection of papers from across a range of societies in different regions of the Austronesian-speaking world, this collection of papers focuses on one particularly diverse region - that of eastern Indonesia. It is hoped that a demonstration of the value of the use of the concept of precedence within this region will prompt a wider consideration of its use in other regions and in other contexts.

\section{Bibliography}

Barraud, Cécile

1990 'Wife-givers as ancestors and ultimate values in the Kei Islands' in Bijdragen tot de Taal-, Land en Volkenkunde 190 (2-3): 193-225.

Boulan-Smit, Christine

2006 'Traditional Territorial Categories and Constituent Institutions in West Seram: The Nili Ela of 'WELE Telu Batai and the Alune Hena of Ma'saman Uwei' in in Reuter, Thomas (ed), Sharing the Earth, Dividing the Land: Land and Territory in the Austronesian World, pp. 157-177. Canberra: ANU E Press.

Dumont, Louis

1980 Homo Hierarchicus: the Caste System and Its Implications. Chicago: University of Chicago Press. 
Fox, James J.

'Origin, Descent and Precedence in the Study of Austronesian Societies'. Public Lecture in connection with De Wisselleerstoel Indonesische Studien given on the 17th of March 1988. Leiden University.

1994 'Reflections on "Hierarchy" and "Precedence"' in Jolly, M. and Mosko, M.(eds), Transformations of Hierarchy: Structure, History and Horizon in the Austronesian World, Special Issue of History and Anthropology 7 (14):87-108.

1995 'Origin Structures and Systems of Precedence in the Comparative Study of Austronesian Societies' in P. J. K. Li, Cheng-hwa Tsang, Ying-kuei Huang, Dah-an Ho and Chiu-yu Tseng (eds), Austronesian Studies Relating to Taiwan, pp 27-57. Taipei: Symposium Series of the Institute of History \& Philology: Academia Sinica 3.

1996 'The Transformation of Progenitor Lines of Origin: Patterns of Precedence in Eastern Indonesia', in Fox, James J. and Clifford. Sather (eds), Origin, Ancestry and Alliance: Explorations in Austronesian Ethnography, pp.130-153.Canberra, Anthropology, Research School of Pacific and Asian Studies.

1998 'Foreword: The Linguistic Context of Florenese Culture' in Antropologi Indonesia, No. 56, pp. 1-12.

'Precedence in Practice among the Atoni Pah Meto of Timor' in Aragon, L.V. and Russell, S. (eds), Structuralism's Transformations: Order and Revisions in Indonesia and Malaysia. Tucson, AZ: Arizona State University, Program for Southeast Asian Studies, Monograph Series Press, 1999: 3-36.

2008 'Installing the 'outsider' inside: the exploration of an epistemic Austronesian cultural theme and its social significance in Indonesian and the Malay World,Vol 36, No 105: 201-218.

Freeman, Derek

2006 The Social Structure of a Samoan Village Community. Canberra: Target Oceania, Division of Pacific and Asian History Research School of Pacific and Asian Studies, The Australian National University

Geertz, Clifford

1980 Negara: The Theatre State in Nineteenth Century Bali. Princeton: Princeton University Press.

Goldman, Irving

1970 Ancient Polynesian Society. Chicago: The University of Chicago Press. 
Graham, Penelope

1996 'Enacting Sovereignty: Sacrifice and the Power of Outsiders in Lewolama, Flores' in Howell, Signe (ed), For the Sake of our Future: Sacrificing in Eastern Indonesia, pp. 148 - 175. Leiden: Research School of CNWS

Grimble, Francis

1989 Tungaru Traditions: Writings on the Atoll Culture of the Gilbert Islands. (Edited by H. E. Maude). Pacific Islands Monograph Series, No 7. Honolulu: University of Hawaii Press.

Grimes, Barbara

1996 'The Founding of the House and the Source of Life:Two Complementary Origin Structures in Buru Society' in Fox, James J. and Clifford. Sather (eds), Origin, Ancestry and Alliance: Explorations in Austronesian Ethnography, pp.199-215.Canberra, Anthropology, Research School of Pacific and Asian Studies.

1997 'Knowing your Place: Representing Relations of Precedence and Origin on the Buru Landscape' in Fox, James J. (ed), The Poetic Power of Place: Comparative Perspectives on Austronesian Ideas of Locality, pp.116-131. Canberra: Anthropology, Research School of Pacific and Asian Studies.

Henry, Teuira

1928 Ancient Tahiti. Bernice P. Bishop Museum Bulletin 48. Honolulu: Bishop Museum Press. (Kraus Reprint, N.Y: 1971)

Hocart, A. M.

1970 Kings and Councillors: An Essay in the Comparative Anatomy of Human Society. Chicago: The University of Chicago Press.

Lewis, E. Douglas

1988 People of the Source: The Social and Ceremonial Order of Tana Wai Brama on Flores. Verhandelingen van het Koninklijk Instituut voor Taal-, Landen Volkenkunde No 135. Dordrecht: Foris.

1996 'Origin Structures and Precedence in the Social Orders of Tana 'Ai and Sikka' in Society' in Fox, James J. and Clifford. Sather (eds), Origin, Ancestry and Alliance: Explorations in Austronesian Ethnography, pp.154-174.Canberra, Anthropology, Research School of Pacific and Asian Studies.

1998 'Don Alésu's Quest: The Mythohistorical Foundation of the Rajadom of Sikka'. History and Anthropology, Volume 11 (1): 39 - 74. 
2006 'From Domains to Rajadom: Notes on the History of Territorial Categories and Institutions in the Rajadom of Sikka'. in Thomas A. Reuter (ed.), Sharing the Earth, Dividing the Land: Land and Territory in the Austronesian World, pp 179-210. Canberra: Australian National University E Press.

McWilliam, Andrew

2002 Paths of Origin, Gates of Life: A Study of Place and Precedence in Southwest Timor. Leiden: KITLV Press.

Mead, Margaret

1930 Social Organization of Manu'a. Bernice P. Bishop Museum Bulletin 76. Honolulu: Bishop Museum Press. (Reprint: 1969)

Molnar, Andrea Katalin

2000 Grandchildren of the Ga'e Ancestors: Social Organization and Cosmology among the Hoga Sara of Flores. Leiden: KITLV Press.

Reuter, Thomas

1993 'Precedence in Sumatra: An Analysis of the Construction of Status in Affinal Relations and Origin Groups' in Bijdragen tot de Taal-, Land en Volkenkunde 148: 489-520.

2002a Custodians of the Sacred Mountains: Culture and Society in the Highlands of Bali. Honolulu: University of Hawaii Press.

2002b The House of our Ancestors: Precedence and Dualism in the Highlands of Bali. Leiden: KITLV Press.

Sahlins, Marshall D.

1958 Social Stratification in Polynesia. Seattle: University of Washington Press.

Sakai, Minako

1997 'Remembering Origins: Ancestors and Places in the Gumai Society of South Sumatra' in Fox, James. J. (ed), The Poetic Power of Place: Comparative Perspectives on Austronesian Ideas of Locality, pp.42-62. Canberra: Anthropology, Research School of Pacific and Asian Studies.

Scott, Michael W.

2007 The Severed Snake: Matrilineages, Making Place, and a Melanesian Christianity in Southeast Solomon Islands. Durham, N.C: Carolina Academic Press.

2008 'Proto-People and Precedence: Encompassing Euroamericans through Narratives of 'First Contact' in Solomon Islands' in Stewart, Pamela J. and Andrew Strathern (eds), Exchange and Sacrifice, pp. 141-176. Durham, N.C.: Carolina Academic Press. 
Siikala, Harri

2008 'The House and the Canoe: Mobility and Rootedness in Polynesia' in Sather, Clifford and Timo Kaartinen (eds), Beyond the Horizon: Essays on Myth, History, Travel and Society, pp. 101-122. Helsinki: Finnish Literature Society.

Therik Tom

2004 Wehali, The Female Land: Traditions of a Timorese Ritual Centre. Canberra: Anthropology, Research School of Pacific and Asian Studies, The Australian National University

Tule, Philipus

2004 Longing for the House of God, Dwelling in the House of the Ancestors: Local Belief, Christianity and Islam among the Kéo of Central Flores. Studia Instituti Anthropos No. 50. Fribourg: Academic Press.

Vischer, Michael P.

1996 'Precedence among the Three Hearth Stones: Contestation of an Order of Precedence in the Ko'a Ceremonial Cycle (Palu'e Island, Eastern Indonesia) in Fox, James J. and Clifford. Sather (eds), Origin, Ancestry and Alliance: Explorations in Austronesian Ethnography, pp.175-198.Canberra, Anthropology, Research School of Pacific and Asian Studies.

Winn, Philip

2006 'Tanah Berkat (Blessed Land): The Source of the Local in the Banda, Central Maluku' in Reuter, Thomas (ed), Sharing the Earth, Dividing the Land: Land and Territory in the Austronesian World, pp.113-133. Canberra: ANU E Press.

\section{ENDNOTES}

${ }^{1}$ Even Louis Dumont refers to 'an order of precedence' in a crucial discussion of his notion of hierarchy in Homo Hierarchicus (see Fox 1994 for a discussion of Dumont's ideas in relation to the idea of precedence).

2 Teuira Henry, in her classic study, Ancient Tahiti, does not use the phrase, 'order of precedence', but instead felicitiously writes of an 'order of prestige' uniting Tahiti, Moorea and the Tuamotus (1928:113)

3 Interestingly, Margaret Mead does not make use of the term precedence in analyzing Samoan social status in her monograph, Social Organization of Manu'a, except briefly in relation to ceremonies in the fono: 'Seating arrangements, precedence in speaking, the serving of kava, are all performed meticulously ...'(1930: 62).

4 These theses include two theses on Flores: 1)Penelope Graham, To Follow the Blood: The Path of Life in a Domain of Eastern Flores (1991) and 2) Michael Vischer, Children of the Black Patola Stone: Origin Structures in a Domain on Palu'e Island, Eastern Indonesia (1992); three theses on islands in Maluku: 3) Barbara D. Grimes, The Pursuit of Prosperity and Blessing: Social Life and Symbolic Action on Buru Island, Eastern Indonesia (1993); 4) Christine Boulan-Smit, We of the Banyan Tree: The Traditions of Origin of the Alune of West Seram (1998) and 5) Phillip Winn, Banda: The Blessed Land: Local Identification and Morality in a Maluku Muslim Community (2002) plus a thesis that examines a society in Sumatra: 6) Minako Sakai, The Nut Can Not Forget Its Shell: Origin Rituals of the Gumai of South Sumatra (1999). 